\title{
METHODOLOGICAL ASPECTS OF THE EXPORT POTENTIAL FORMATION OF RUSSIA IN THE CONTEXT OF TRANSFORMATION OF THE EXTERNAL SECTOR OF THE ECONOMY
}

\section{Andreev Oleg 1}

\section{Abstract}

The relevance of this article is predetermined by the existence of interdependent problems that have matured in Russia at the current stage of modernization of its economy, by the need to formulate an export strategy and adapt the country's economy to the conditions of entering the top five world economies. At the present stage, Russia is improving measures of investment, institutional and other policy areas that form the country's overall economic policy. The main components of scientific novelty are the stimulation of domestic exports, ensuring the demand for goods and services on a longterm basis, as well as the development of new types of industries with the expansion of the non-primary sector oriented to export. There is a need to develop an effective foreign trade development strategy for the country, since further measures to develop commodity markets play an important role in shaping the country's macroeconomic indicators.

Key words: innovation. export, export behavior, competitiveness, development strategy, world economy, export strategy.

doi: http://doi.org/10.15350/F_7/8

\section{Introduction}

The implementation of the national export strategy of the Russian Federation necessitates the creation of an effective public administration system and an adequate institutional environment.

One of the conditions for increasing the export potential of Russia is the implementation of the innovation development strategy and support for domestic industrial enterprises, taking into account the national component.

The strategic field of activity should be aimed at increasing investment in the ports of the world, what allows the country to own information on all trade operations, to expand knowledge and the prospect of participation in the global trade communication chain.

Investing in port terminals of the world should become a component of investment capital. This will allow to conduct a focused research on the study of investment opportunities in the ports of the world, to apply the experience of miscalculation management in the port business, as well as to negotiate with relevant departments to invest in this area.

To improve the export of domestic products, it is necessary to support highly innovative industries with a widely attracted range of investment capital, contributing to the expansion of export opportunities of the country's economy, as well as measures to increase labor productivity. We need training for specialists in high-tech industries, such as machine tool building, bioengineering, nanotechnology, automation, which can be

\footnotetext{
${ }^{1}$ Andreev Oleg, Ph.D. in Economics, associate professor, Department of Economics, Organization and Strategy for Enterprise Development, Samara State Economic University, Russia.
} 
trained in linked industries related to the service sector (logistics, certification and standardization, marketing promotion, etc.).

The transfer of technology and knowledge should become a new tool for the technological development of production. To improve the situation in the country, a national concept is needed to conduct research and practical application in the field of standardization and certification. In order to upgrade the technological base of production, the latest technological equipment should be provided through investment projects on a leasing basis, which should be accompanied by a package of new services for the manufacturer.

The foregoing indicates the need for a thorough study of the formation of export potential from methodological positions.

The use of economic development mechanisms in the context of Russia's integration into the global economy indicates the urgency of developing the country's export potential

\section{Methodology}

In modern economic literature there are various methods for assessing export potential and its competitiveness. Methodological aspects were considered in the studies of the authors of Bernard et al., Farole et al., Meilien and Sniesko, Mikael P. Todaro, Paul R. Krugman, Morris Obstfeld, Thomas A. Pugel, Peter H. Lindert, J. Stigler, Maurice Allais, F. Justster, E.M. Aghababyan.

Works of J. Robinson, V. Nordhau, P. Samuelson, R. Solow, J. Stigler, L. Erhard are focused on maintaining the sustainability of macroeconomic processes.

In the work of J. M. Keynes, A. Muller-Armak, I. Kant, V.N. Khrapanyuk and others are devoted to the need to regulate economic processes. Their studies on state regulation and substantiation of the functions of the state in the economy are relevant now.

Research questions involve the formulation of specific tasks, without the resolution of which it is impossible to realize the plan. There are issues that can be solved through existing scientific data (for example, methodological). Moreover, many scientific results need to be refined using modern approaches [1].

It should be noted that the directions of the theoretical and methodological substantiation for ensuring sustainability at the national, regional and sectoral levels and the study of ways to create export potential are insufficiently studied. In economic studies, the problems of export potential in the context of globalization have not yet received adequate coverage. The level of scientific knowledge in the country in the field of export potential is not sufficient to solve fundamentally new problems and problematic issues.

In this regard, research in this direction can increase the competitiveness of the country's organizations, which will affect the formation of export potential.

The formation of export potential requires the systematization of different views, therefore it is legitimate to introduce the essence of export potential into existing interpretations, which allows us to highlight several points of view [2].

So, scientists consider the export potential as a qualitative characteristic of the national economy, that is, the potential ability of a country to export products, resources that are currently available or produced, ranking factors such as sources, reserves, funds and opportunities as an object of export.

It is rightfully to consider the characteristics of the export potential from other perspectives: as a complex multifaceted phenomenon, which is revealed with simultaneous perception of it as an "indicator", "process", "behavior", a quantitative characteristic of the economic parameters of economic development.

Consideration of the export potential as a special process makes it possible to reflect the "process nature" of production and the export activity itself. 
So, O'Donnell considers marketing opportunities for export potential [3], which is more relevant than ever in modern conditions, since export potential reflects the process nature of production and export activities.

A. Buckley et al. Consider export potential as a certain process that determines the presence of factors such as labor costs, productivity, prices and R\&D [4].

In practice, often export potential is used as an "indicator" of economic potential.

$\mathrm{Yu}$. Savinov et al. [ 5 believe that this indicator should take into account the market for the possible sale of its goods, since export potential is, first of all, the ratio of exports to total sales.

In modern economic science there is also such an understanding as "exportbehavior", which characterizes marketing innovations.

Castro et al. made an attempt to determine how much export value and productivity together can determine intra-company export behavior [2].

M. Thomas and L. Araujo consider export behavior as an innovative strategy [7].

In our opinion, in the economic literature, opinions on choosing the optimal export strategy differ.

But in the economic literature, opinions on choosing the optimal export strategy differ. A. Smith, D. Ricardo, Heckscher-Olin, and Samuelson argue that countries should specialize in manufacturing and exporting in accordance with their comparative advantages.

This argument was supported by empirical evidence of E. Helpman and P. Krugman, R. Housman, D. Rodrik. These authors adhere to the export specialization strategy. They emphasize that this nature of specialization is gaining importance as specializing in this type of export of products, which may be accompanied by a deterioration in economic indicators.

Under conditions of uncertainty in general, global trade will decline, as commodity producers are at risk of declining output.Other arguments in favor of export diversification include mitigating the vulnerability of countries to economic shocks (such as volatility and instability of export operations; reducing the fluctuation in economic growth in countries) that open up to trade.

The export strategy based on the global value chain (GVC), implemented through the country's accession to the GVC, is being modernized by the inclusion of additional internal added values.

According to supporters, despite the similarities with the industrialization strategy, there is a difference (A. Hirschman in the late 1950s), which consists in the constant search for microefficiency that controls GVCs around the world, which is a condition for the long-term sustainability of GVCs modernization strategies.

The GCCs modernization strategy more often implies an increase in internal intersectoral relations. This strategy is sustainable in the long run if new domestic suppliers can effectively replace foreign ones.

The essence of export potential is not represented in the economic literature. Therefore, the content is more fully revealed when characterizing its types, which are differentiated by spatial (regional and global), temporal (realized and unrealized), qualitative (level of competitiveness) signs and levels.

In the scientific literature, special attention is paid to spatial concepts, including the "regional" or "world" levels.

In this regard, "export potential" means the ability to produce the required amount of export-oriented goods that would meet the quality of the needs of the external market region. Accordingly, we can assume that the export potential of the country is made up of the export potentials of individual industries. This concept also includes the company's 
ability to find partners in foreign markets, the ability to conclude mutually beneficial contracts for the provision of services necessary for consumers.

Temporal characteristics distinguish between realized and unrealized potential.

The realized export potential, in our opinion, assumes that the goods or services have been successfully identified and they entered the foreign market.

The unrealized export potential implies that export outside the country is not possible for objective and subjective reasons.

We believe that this phenomenon lies not only in the realization of market opportunities, but also in the ability to form a mechanism for future development and implies the presence of internal capabilities to adapt the system to changing external conditions.

In different periods, the transformation of export potential took place.

Many scientists support the idea of a significant level of the relationship between technology and export, but the scientific value of technology for competitiveness does not always depend on its use in manufacturing products. It is important what technologies and how they were used.

According to M. Tarasov, technologies as a competitive advantage are considered as a link in the chain of value creation factors [10].

Competitiveness issues need to be addressed through new technologies. Emphasis needs to be placed on upgrading existing technologies through the promotion of green technologies and organic products. Thus, a gradual transition of the industrial structure of the economy to "bioeconomics" is important for Russia. For this, the country has all the natural conditions: vast territory, natural resources and organic intermediate products.

Uchida and Cook, analyzing the commercial and technological advantages of Asian countries, note a significant difference in them, associated primarily with the structure of industry, the relationship between technology and industry structure.

The impact of innovation on export potential does not occur directly, but through impact on the industry. Innovations have become an economic resource in determining the competitiveness of industry, although previously they were only considered as its source.

Thus, the accumulation of changes is necessary to obtain as a result of a major technological breakthrough. An innovation policy will be effective if there is a systematic relationship between two main areas: the stimulation of human potential and the development of an innovative type of business sector. The fact that innovations in some countries are applied mainly due to foreign direct investment negatively affects innovative development.

Lee explains that each economic system has certain institutions - social, economic, political, through which the conditions for competition between market participants are formed.

A number of scientists in their works apply an integrated approach to determining the parameters of export potential.

B. Khusainov offers an approach to identify the comparative advantage of exports by including additional indicators in the production and consumption of products [9].

J. Brunekiene and D. Paltanavikine [14] believe that using the index is the best way to measure export competitiveness.

J. Mikulis and J. Ruzevikus emphasize the development of a model for measuring export competitiveness through export competitiveness factors and their characteristic indicators.

The methodological approach is predetermined by the parameters characterizing the export potential as the ratio of exports to total sales, the share of competitive export 
products, the ratio of exports to the domestic market, exports as a percentage of total production, as well as export volumes.

There are still debatable issues of quantitative assessment of barriers and determining the effects of influence on export potential.

This problem was considered by such researchers as Didov, Maskus, Naylor, who developed a number of methods that make it possible to measure barriers to the realization of export potential and assess their impact. The most common methods are determining the frequency of use, the price gap, i.e., the price or tariff equivalents of NTBs, simulation of foreign economic activity.

The analysis of the existing literature on competitiveness reveals a wide range of concepts and the extreme difficulty of applying various techniques to measure these barriers.

Theoretical and practical issues of export productivity are analyzed in the studies of Hausman et al. In these studies, improving the export structure was associated with diversification, which includes improving export quality and is measured by export productivity [3].

There are several models used by different groups of countries:

- an industrial model of export development using an assortment strategy;

- an investment model for the development of exports, involving the use of various investment strategies;

- a market model for export development using a market penetration strategy;

- a modernization model of export development based on productivity.

To increase export potential by expanding the market, analysis is needed to assess and select a market for promoting export flows from a country where Q1 is the possibility of expanding exports for existing goods and Q2, in addition to existing goods, the possibility of expanding the export of new goods in new markets.

There are ways to diversify the goods, that is, to diversify goods by creating other, not similar to each other, through the production of related goods.

\section{Results}

Houseman and Klinger take the "product space" model as the basis for determining export potential.

The results of the analysis will help answer the question, what are the opportunities in the country's economy for transformation. The calculation is as follows: the level of comparative competitive advantages of goods is determined by the Balass method according to the following formula (1):

$$
R C A_{2}=\frac{\left(X_{i j}-M_{i j}\right)}{\left(X_{i j}+M_{i j}\right)}
$$

where $\mathrm{M}_{\mathrm{ij}}$ - import of product $\mathrm{j}$ into country I, and then the distance between goods I and $\mathrm{J}$ in the year $\mathrm{T}$ is measured, where this distance is called "proximity", it is equal according to formula (2):

$$
\varphi_{i, j, t}=\min \left\{P\left(x_{i, t} \mid x_{j, t}\right), P\left(x_{j, t} \mid x_{i, t}\right)\right\}
$$

where for any country according to the formula (3):

$$
x_{i, c, t}=\left\{\begin{array}{lr}
1 & \text { if } R C A_{i, c, t}>1 \\
0 & \text { otherwise }
\end{array}\right.
$$


A country's ability to transition to new products depends on whether it is easy to reorient its existing potential to the production and export of new products. For example, if Malaysia exports microwave ovens, and Chile specializes in exporting salmon, then in the first case, a deep knowledge of electronics and technology is required, in the second, knowledge of biology and veterinary medicine. And it's hard to say which of the methods leading to increased economic growth is more advanced or complex.

Thus, it is easier for export to establish the production of a related product than not at all similar, which may require such capabilities that the country has not yet accumulated for its production, which makes it possible to identify:

-how it is possible to replenish the existing export basket with new goods so that they are successfully exported and competitive;

-it makes it possible to trace the relationship between existing and new products through the concept of "distance".

Currently, there are modified versions of the Husman-Klinger method, but it has limitations.

According to the product space model, the choice of a new product is based on the accumulated capabilities of the country, however, the accumulated opportunities are not always the result of the implementation of a well-thought-out policy of the country in the formation of the export basket.

Based on the existing opportunities and available resources in the country, it is easier to reorient to "close" goods, which will provide the export basket with a clear advantage (under the concept of available opportunities and resources, we can consider human potential, institutional opportunities, export basket, etc.)..

Additional parameters are also needed, such as the state of demand for goods in the foreign market and domestic production capabilities.

In the absence of a universal method for assessing export potential, different methods can be applied and interconnections between their indicators can be established.

Therefore, one of the important principles of trade policy is functioning countries in market conditions, whose trading activities include a non-discriminatory basis in relation to the partner. Therefore, public policy should operate on the principles of legitimacy of the measures taken, transparency and justice in relation to partners.

\section{Conclusion}

Export, like import, is a product of a separate stage of the technological process. The implementation of intra-industry trade opens up opportunities for the mutual exchange of innovations and technologies, increasing the economic potential, searching for new directions in terms of differentiating the product range, liberalizing foreign trade, and eliminating barriers in foreign trade, lower tariff rates, growth in foreign direct investment.

Expanding market coverage for products that have proven to be competitive in some export markets can be an important channel for improving export assortment.

In modern conditions, it is supposed to transform the export model and transfer it to a new level - the level of innovative development.

In the process of research, the need arises to differentiate the results of export analysis by industry and country and present them in an aggregated form, as well as to identify promising niches and markets for promoting export products of a group of goods that have comparative advantages of the Russian Federation in certain markets.

The main trends in the development of foreign trade of Russia:

- the value of exports has decreased sufficiently;

- the physical volume has significantly decreased, but not so rapidly; 
- the range of exported goods has increased;

- there were structural changes in the export basket. istics:

Export potential can be assessed in terms of quantitative or qualitative character-

-quantitative characteristics - "volume and growth" of exports,

•qualitative characteristics - "competitiveness", "diversification", "productivity" of exports, etc.

By identifying the quantitative and qualitative characteristics of exports, it is possible to determine the level of development of export potential by a certain indicator, a change in competitiveness, an increase in export volume, etc.

A study of the main factors affecting exports made it possible to identify the nature of their influence on the country's economic indicators. follows:

The ranking of influencing factors on the export of products is presented as

- the factor of natural resources has recently lost its significance;

- the fluctuation of the national currency as one of the components of the macroeconomic environment of the country causes mixed estimates;

- the role of the institutional environment is decreasing.

New technologies, innovations and government measures stimulating exports can have a qualitative impact on exports.

But no method can independently assess the export potential, since they are components of a systemic methodology that determines the sequence of their use, establishes their relationships, which ultimately makes it possible to get the most comprehensive analysis of the country's export potential.

In this regard, the creation of the so-called "block model" is required, which includes a combination of several models, since it is difficult to cover the above goals with one model.

Thus, the choice of assessing the export potential acceptable for Russia involves the development of methods, the results of which should give answers to questions such as:

-to improve the volume and growth of export products and the volume of work associated with export activities;

-to diversify the commodity structure of export products and expand sales markets;

-to improve the quality of export products and the quality of work related to export policy.

Currently, new technologies are being introduced in the global economy that can affect the development of such areas of the economy as the communications industry, aviation, metallurgy, construction, energy, agriculture, bioengineering, mechanical engineering, etc. New types of technologies are already being introduced: FIN-tech ; cyber technology; hydrogen fuel cell vehicles with zero emissions; next-generation robotics working remotely from the manufacturing process; recyclable thermosetting plastics new types of plastic for cutting field waste, computer chips that mimic the human brain; replacement of metals with other forms of materials, the digital genome, etc.

Recommendations on improving export policy, which can help accelerate economic growth and further develop foreign economic activity of Russia as a factor of integration into the world economy.

\section{References}

[1] Ermakova A.A. Theoretical approaches to the definition of the concept of "economic potential" // Young scientist. - 2016. - No. 10 (114). - P. 15-19. 
[2] Zemtsov S., Barinov V. The paradigm shift of the regional innovation policy in Russia: from leveling to clever specialization // Issues of economics. - 2016. - No. 10. - P. 65.

[3] O'Donnell M., Turner M. Exporting new public management: performance agreements in a Pacific microstate // International Journal of Public Sector Management. - 2005. - Vol. 46, №7. - P. 615-628.

[4] Barkley D. Evaluations of regional competitiveness: making a case for case studies // http://journal.srsa.org/ojs/index.php/RRS/article/view/158/107.

[5] Savinov Yu. et al., Export potential of the industry for the development and marketing of information and communication technologies // Russian Foreign Economic Bulletin. - 2013. No. 6. - P. 28-40.

[6] Mancini-Griffoli T., Pauwels L. Is there a euro effect on trade? An application of end-of-sample structural break tests for panel data, IHE: working papers / The Graduate Institute of International Studies. - Geneva, 2006. - Vol. 4. - P.1-31.

[7] Thomas M., Araujo L. Theories of Export Behaviour: A Critical Analysis' // European Journal of Marketing. - 1985. - Vol. 19, №2. - P. 42-52.

[8] McCreadie K. Smith's A. The wealth of nations: A modern-day interpretation of an economic classic. - Oxford, 2009. - $126 \mathrm{p}$.

[9] Ricardo D. On the principles of political economy and taxation. - ed. 3 // http://www.efm.bris.ac.uk/het/ricardo/Principles.pdf.

[10] Tarasov M. et al. Competition and competitiveness of economic entities in economic sectors: lecture course. - Yakutsk, 2014 - - 334 p.

[11] Álvarez I., Marin R., Fonfría A. The role of networking in the competitiveness of firms // Technol. Forecast. Soc. Change. - 2009. - Vol. 76, №3. - P. 410-421.

[12] Thompson E.R. National competitiveness: A question of cost conditions or institutional circumstances? // Br. J. Manag. - 2004. - Vol. 15, №3. - P. 197-218.

[13] Lee C. An institutional perspective of national competitiveness // Singapore Economic Review. - 2010. - Vol. 55, №4. - P. 671-683.

[14] Bruneckiene J., Paltanaviciene D. Measurement of export competitiveness of the Baltic States by Composite Index // Engineering Economics. - 2012. - Vol. 23, №1. - P. 50-62. 